\title{
Dari Hegemonic Party ke Market Oriented Party: Studi tentang Political Marketing Partai Golkar
}

\author{
Arsad Idrus ${ }^{1}$, Niken Febrina Ernungtyas ${ }^{2}$, Guntur Freddy Prisanto ${ }^{3,}$ \\ Anindita Lintangdesi Afriani ${ }^{*}$ \\ 1Sekolah Tinggi Ilmu Komunikasi Inter Studi Jakarta \\ 2Sekolah Tinggi Ilmu Komunikasi Inter Studi Jakarta \\ 3Sekolah Tinggi Ilmu Komunikasi Inter Studi Jakarta \\ 4Sekolah Tinggi Ilmu Komunikasi Inter Studi Jakarta \\ *Email: lintangdesi@gmail.com
}

\section{How to Cite This Article:}

Idrus, A., Ernungtyas, N. F., Prisanto, G. F., \& Afriani, A. L. (2020). Dari Hegemonic Party ke Market Oriented Party: Studi tentang Political Marketing Partai Golkar. EXPOSE: Jurnal Ilmu Komunikasi, 3(2), 165-176.
Received: $29-10-2020$

Revision: 25-02-2021

Acceptance: 25-03-2021

Published online: 04-07-2021

DOI: $10.33021 /$ exp.v3i2.1285

English Title: From Hegemonic Party to Market-Oriented Party: Study on Political Marketing of the Golkar Party

\begin{abstract}
The Golkar Party is a party with a big name in Indonesia with a dominant political power in its heyday of 32 years. Golkar's most significant strength was that it was often the object of news in the mass media because it was considered to represent the government. However, since Reformasi, Golkar was faced with a reality that made Golkar have to re-adapt and develop a new strategy in political communication. This research aims to identify the political system, especially in terms of political communication management and political marketing used by the Golkar Party. The research method used a descriptive-analytical qualitative approach obtained through in-depth interviews with three informants selected purposively according to the research needs. The research results explain that, first, Golkar political communication uses a new paradigm of socialization strategy applied in various significant events and activities and training for cadres and members. Second, the Golkar party's political marketing is through a market-oriented party approach that adapts political products to the needs of society.
\end{abstract}

Keywords: Golkar Party, Hegemonic Party, Market Oriented Party, Political marketing

Abstrak Partai Golkar merupakan partai dengan nama besar di Indonesia dengan kekuatan politik yang dominan pada masa kejayaan mencapai 32 tahun. Kekuatan terbesar Golkar di masa itu adalah sering menjadi objek pemberitaan di media massa karena dianggap mewakili pemerintah. Namun, semenjak Reformasi, Golkar dihadapkan pada kenyataan yang membuat Golkar harus kembali beradaptasi dan membangun strategi baru dalam komunikasi politik. Tujuan penelitian ini adalah untuk mengidentifikasi sistem politik terutama dari sisi manajemen komunikasi politik dan penerapan marketing politik yang digunakan oleh partai Golkar. Metode penelitian menggunakan pendekatan kualitatif desktriptif-analitis yang didapatkan melalui hasil wawancara mendalam dengan tiga informan yang dipilih secara purposive sesuai dengan 
kebutuhan penelitian. Hasil penelitian menjelaskan bahwa, pertama komunikasi politik Golkar menggunakan strategi sosialisasi paradigma baru yang diterapkan dalam berbagai acara dan kegiatan besar, serta pelatihan-pelatihan kader dan anggota. Kedua, adapaun pemasaran politik yang digunakan partai Golkar adalah melalui pendekatan market-oriented party yang menyesuaikan produk-produk politik dengan kebutuhan masyarakat.

Kata Kunci: Hegemonic Party, Market Oriented Party, Partai Golkar, Political marketing

\section{PENDAHULUAN}

Partai Golkar pasca reformasi dalam Pemilu 2004 kembali meraih dominasinya sebagai partai peraih suara terbanyak melampaui pemenang Pemilu 1999, PDI Perjuangan (Ali, 2004). Fenomena semacam ini tentu mengandung "misteri politik" tersendiri yang harus dijelaskan, mengapa rakyat pada akhirnya memberikan kepercayaan kembali pada partai yang pada lima tahun sebelumnya (Pemilu 1999) justru menjadi partai yang paling dihujat massa.

Menurut Tomsa (2007), ada banyak alasan yang bisa menjelaskan mengapa Golkar bisa muncul kembali sebagai kekuatan politik dominan pada Pemilu 2004. Pertama, Partai Golkar telah "menggunakan" media massa sedemikian rupa untuk mempertahankan posisi kuatnya dalam sistem kepartaian pasca-Soeharto. Kedua, peliputan media atas isu-isu itu telah membantu Golkar untuk "sell its new double identity to broader public".

Tomsa (2007) mengatakan bahwa di antara tahun 1998 dan 2004 telah terjadi perubahan signifikan dalam cara media memberitakan Golkar. Perubahan ini lebih bersifat "membantu" daripada "melukai" upaya Golkar untuk membangun sebuah "identitas ganda" (dual identity), yaitu adanya elemen-elemen konservatif pendukung status quo di satu sisi dan elemen-elemen progresif reformisme di sisi lain. Identitas ganda yang "dijual" Golkar dan disebarkan dengan baik oleh media massa ini yang membantu partai Golkar untuk menjaga dukungan dari pemilih tradisionalnya dan menarik dukungan luas dari para pemilih baru di Indonesia (Tomsa, 2007).

Golkar tidak diragukan lagi sebagai partai politik yang menjadi "Newsmaker" paling diminati media untuk diliput dibandingkan partai-partai lainnya (Tomsa, 2007). Berdasarkan riset kuantitatif yang dilakukannya terhadap pemberitaan di harian The Jakarta Post antara Mei 1999 dan Oktober 2006 dihasilkan kesimpulan bahwa tidak ada partai yang disebutkan namanya di harian itu sesering Partai Golkar. Peliputan atas Partai Golkar selama tahun 2004 sendiri menunjukkan, Golkar termuat dalam lebih dari 1000 artikel di harian tersebut dan disebut di lebih dari 100 artikel headline. Bersama dengan PDI Perjuangan, Golkar mendapatkan lebih banyak perhatian dari harian ini dibandingkan dengan partai-partai lain yang lebih kecil (Tomsa, 2007).

Kondisi yang hampir serupa terjadi di sektor media elektronik. Hasil monitoring yang dilakukan oleh Institut Studi Arus Informasi (ISAI) menunjukkan bahwa liputanliputan media televisi terhadap proses kampanye Pemilu 1999 sangat menguntungkan Partai Golkar (Sudibyo, 2004). Kegiatan-kegiatan Partai Golkar mendapatkan liputan paling besar di antara partai lain. Sumber-sumber berita dari Partai Golkar juga 
mendapatkan kutipan yang jauh lebih besar dari sumber-sumber yang kritis pada Partai Golkar. Hal itu merupakan hasil pemantauan ISAI terhadap pemberitaan media elektronik atas proses kampanye parpol-parpol peserta Pemilu 1999 yang dilakukan pada masa kampanye resmi 19 Mei--4 Juni 1999 serta pada masa minggu tenang. Pemantauan dilakukan terhadap seluruh televisi swasta: RCTI, SCTV, Indosiar, TPI, ANTV, dan TVRI.

Menurut (Sudibyo, 2004), ketika publik menunjukkan kritisisme yang meningkat terhadap Partai Golkar, media-media televisi justru bersikap sangat favourable terhadap partai ini. Media televisi menampilkan citra Golkar sebagai partai yang toleran, cinta damai, dan tidak menghalalkan cara-cara kekerasan. Gambaran citra semacam itu muncul dalam berita-berita tentang kekerasan yang dialami oleh Partai Golkar dan dihadapi oleh unsur-unsur Golkar di berbagai daerah di masa kampanye Pemilu. Media televisi juga menggambarkan Golkar sebagai partai yang pro-reformasi dan menolak status quo. Hal itu digambarkan oleh TPI, ANTV, Indosiar dan RCTI selama Mei-Juni 1999. Selain itu, ketika publik membicarakan dugaan penyelewengan dana Jaring Pengaman Sosial (JPS) oleh Golkar dan PDR yang dilontarkan oleh Wardah Hafidz, televisi swasta justru banyak menggunakan jam tayangnya untuk melakukan counterargument dan menampilkan citra Golkar yang bersih dari praktik money politics dengan cara menampilkan banyak narasumber dari Golkar.

Dari sisi media cetak, gerakan reformasi politik pada tahun 1998 juga menghasilkan sejumlah perubahan signifikan di bidang media massa. Menurut Hidayat dalam Dhani (2004), dengan berakhirnya rezim Orde Baru, maka industri pers di tanah air juga mengalami perubahan struktural yang amat signifikan sebagai akibat dari tuntutan reformasi. Perubahan itu diawali dengan adanya deregulasi industri pers dengan dicabutnya Permenpen No. 01/Per/Menpen/1984 tentang ketentuan Surat Izin Usaha Penerbitan dan Pers (SIUPP) yang kerap dijadikan dasar penutupan media massa.

Ketika media sudah merupakan sebuah industri dalam sebuah ekonomi pasar, menurut Hidayat (dalam Dhani, 2004), keberhasilan beragam aktor politik seperti presiden, parlemen atau parpol, lebih ditentukan oleh kemampuan untuk menerapkan suatu strategi manajemen hubungan dengan media dibanding dengan pendekatan represif dan kontrol. Menurut Hidayat (dalam Dhani, 2004), rezim Orde Baru memunculkan tekanan struktural yang memaksa rezim untuk menjalankan pendekatan persuasif dan represif. Dengan kata lain, rezim Orde Baru mampu menciptakan surplus akses ke media, merekayasa legalitas untuk mengontrol isi media, memonopoli distribusi serta pencabutan lisensi bahkan menyeleksi pekerja media, walaupun tidak mampu sepenuhnya menggunakan media sebagai instrumen efektif.

Di era reformasi, pentingnya penerapan suatu manajemen komunikasi dengan media massa oleh parpol menjadi tidak terelakkan lagi. Khusus bagi Golkar, sejumlah perubahan aturan yang terkait dengan media massa membuat para petingginya harus beradaptasi secara cepat dan merumuskan strategi baru. Golkar, yang sebelumnya 
diuntungkan dengan adanya sejumlah "Politik Komunikasi" pemerintah terhadap media massa, kemudian kehilangan pegangannya dan merasa perlu untuk merumuskan strategi "Komunikasi Politik" baru yang lebih bersandar pada upayaupaya persuasif dan pencitraan dibanding upaya-upaya kontrol media massa yang selama masa Orde Baru dilakukan pemerintah, yang juga merupakan elit Golkar.

Pencapaian Golkar sebagai partai politik hingga saat ini tidak lepas dari perubahan dan hal-hal baru. Golkar melakukan sejumlah adaptasi nilai-nilai dan melakukan restrukturisasi organisasi serta jaringan untuk menghadapi lingkungan eksternal baru yang telah berubah menjadi demokratis. Adaptasi itu kemudian berhasil karena didukung oleh sejumlah faktor. Menurut Pujono, Muktiyo, dan Hastjarjo (2015), faktor-faktor tersebut meliputi pencitraan, personalisasi, imajinasi, persuasi, dan upaya meyakinkan orang dan politikus partai politik yang ada. Untuk alasan itu, perencanaan komunikasi politik, kebijakan dan strategi komunikasi politik menjadi sangat krusial dalam hal memenangkan persaingan.

Komunikasi politik merupakan fungsi sosialisasi dan budaya politik yang dalam prosesnya tidak terlepas dari unsur-unsur komunikasi pada umumnya (Muchtar, 2013). Hal ini sejalan dengan pendapat yang dikemukakan oleh Muchtar (2016) bahwa dalam melakukan suatu analisis komunikasi politik, maka fokus utamanya tidak lain adalah struktur-struktur pelaksana fungsi politik dan bagaimana pelaksanaannya dari komunikasi tersebut. Seperti yang juga diungkapkan oleh (McNair, 2011) yang mendefinisikan komunikasi politik sebagai "purposeful communication about politics".

Lebih lanjut (McNair, 2011) menyatakan komunikasi politik, khususnya bagi parpol, bisa mengambil dua bentuk yaitu iklan politik menggunakan asumsi-asumsi political marketing, dan public relations sebagai taktik pengelolaan media dan informasi. Nimmo (2005) menyatakan bahwa pemasaran politik merupakan sebuah produk politik yang terbagi dalam empat hal sebagai berikut: (1) policy (kebijakan), meliputi isu dan program kerja; (2) person, meliputi kandidat dan para pendukungnya; (3) party (partai), meliputi ideologi, struktur, visi-misi partai; dan (4) presentation, yakni medium komunikasi atau konteks simbolis.

Sejalan dengan konsep yang dikemukakan oleh (Lees-Marshment, 2003), pemasaran politik menggunakan produk, penjualan, dan orientasi pasar untuk membedakan berbagai jenis perilaku. Maksud hal tersebut diperjelas oleh Saputra, Haryono, dan Rozikin (2013) bahwa pemasaran politik adalah kegiatan membuat program yang berhubungan dengan permasalahan teraktual yang dilakukan oleh sebuah partai politik atau seorang kandidat.

Dengan kata lain, prinsip-prinsip pemasaran diterapkan dalam kehidupan politik. Hal ini sejalan dengan pemikiran Pujono et al., (2015) yang menyatakan bahwa pemasaran politik mencakup segala aspek politik, seperti calon, partai politik, dan pemerintahan. Seorang kandidat dapat dianggap sebagai produk karena produk harus diperkenalkan kepada konsumen (masyarakat atau publik). Metode pemasaran politik 
mengarahkan politisi untuk mendengarkan hal-hal yang diinginkan masyarakat sehingga calon (kandidat partai politik) dapat meninjau ulang dan menyempurnakan kebijakan, serta menerapkan program dan kebijakannya.

Pengertian lain yang sejalan dengan hal-hal yang telah disebutkan dikemukakan oleh (Firmanzah, 2012), pemasaran politik merupakan suatu proses yang diawali dengan serangkaian pengumpulan informasi, pemetaan, dan analisis semua masalah, hingga kemudian perumusan solusinya. Menurut Maryani (2015), pemasaran politik setidaknya mempunyai beberapa kata kunci yang dapat diperhatikan, yaitu kegiatan, partai, kandidat yang membawa partai, konsep pemasaran, pemilih, citra, reputasi dan kepemimpinan; serta perumusan dan kebijakan keluaran.

Terdapat tiga pendekatan marketing politik yang dikemukakan oleh LeesMarshment (2009) yakni Product-Oriented Party (POP), Sales-Oriented Party (SOP) dan Market-Oriented Party (MOP). Pada POP atau product oriented suatu organisasi politik, pemimpin melakukan kegiatan perancangan kebijakan dan mengharapkan dukungan dari para anggota dan publik. Model pendekatan ini lebih mengutamakan argumentasi, nilai, dan norma dari partai yang diharapkan dapat membentuk kepercayaan dari pemilih atau publik terhadap partai tersebut. Pendekatan SOP berfokus pada strategi komunikasi yang dilakukan suatu partai politik dengan melakukan tindakan membujuk para pemilih dan publik untuk memilih dan menginginkan hal-hal yang ditawarkan partai tersebut. Pendekatan ini fokus menjual produk partai seperti halnya dalam komunikasi pemasaran. Pendekatan MOP menitikberatkan pada prioritas publik yang didapatkan dari berbagai metode pengumpulan data, seperti polling, focus group discussion, konsultasi, pertemuan, wawancara, rapat, dan diskusi internal. Pendekatan ini lebih mengutamakan hal-hal yang diinginkan oleh publik kemudian disesuaikan dengan produk-produk politik. Pada studi ini diketahui bahwa Golkar tengah menerapkan pemasaran politik dengan pendekatan market-oriented party.

Partai Golkar sempat menjalani pemasaran politik dengan pendekatan hegemonic party. Sistem kepartaian hegemonik ini muncul setelah Golkar menang secara meyakinkan dalam Pemilu pertama Orde Baru tahun 1971. Dengan dukungan dan bantuan dari militer dan birokrasi, Golkar menjadi "the hegemonic party" dan memiliki kemampuan untuk menyuarakan dan menetapkan apa yang harus menjadi agenda politik bagi seluruh bangsa, termasuk bagaimana tata cara penyelenggaraan pemilu, pengorganisasian kembali partai-partai dan manajemen organisasi-organisasi massa.

Menurut Suryadinata (2007), kekuatan Golkar di era Soeharto sangatlah melimpah dan tidak ada kesempatan sedikitpun bagi partai-partai oposisi untuk berbagi kekuasaan, apalagi ikut memikul kekuasaan. Namun, sistem partai hegemonik itu kemudian hanya mampu bertahan selama 27 tahun (1971-1998) untuk kemudian digantikan dengan sistem multi-partai. Sejak 1998, sistem partai hegemonik di Indonesia berakhir dan Indonesia masuk ke dalam sistem multi-partai di mana Golkar, meski tetap yang terbesar, namun harus mampu bersaing dengan partai-partai lain. 
Terkait dengan itu, studi ini ingin menganalisis penerapan marketing politik yang dilakukan oleh partai Golkar dalam menghadapi perubahan sistem politik terutama dari sisi manajemen komunikasi politik.

\section{METODOLOGI}

Penelitian ini merupakan sebuah penelitian kualitatif yang bersifat desktriptifanalitis. Jenis penelitian termasuk dalam penelitian studi kasus. Menurut (Neuman, 2014) studi kasus digunakan untuk memperoleh gambaran dari sekumpulan kecil kasus dengan berfokus pada banyak detail dalam setiap kasus dan konteks. Dalam hal ini, konteks kasus fokus pada kegiatan marketing politik partai Golkar.

Adapun metode pengumpulan data dalam penelitian ini melalui data primer dan data sekunder. Data sekunder adalah penelaahan dokumen tertulis dalam bentuk literatur kepustakaan seperti artikel di buku, jurnal atau jenis-jenis dokumen tertulis lainnya yang dinilai relevan dengan objek studi kasus ini. Kumpulan literatur tersebut merupakan data sekunder yang digunakan untuk melengkapi data primer yang didapatkan dari hasil wawancara mendalam dengan tiga informan yang dipilih secara purposive berdasarkan keterkaitannya dengan fokus penelitian. Menurut Bryman (2012), wawancara mendalam merupakan wawancara yang terstruktur.

\section{HASIL DAN DISKUSI}

\section{Manajemen Komunikasi Politik Golkar}

Sebagai salah satu partai politik di Indonesia yang memiliki nama besar dan posisi tinggi, partai Golkar terbukti mampu mempertahankan manajemen komunikasi politik atau bisa disebut juga dengan strategi komunikasi. Menurut McNair (2011), bentuk komunikasi politik terdiri atas iklan politik dan hubungan masyarakat. Iklan politik partai Golkar yang utama dilakukan melalui kegiatan kampanye, baik melalui media konvensional maupun media baru.

Kampanye bagi partai Golkar adalah penyampaian visi, misi, platform perjuangan, doktrin, dan program, serta kinerja partai Golkar. Kegiatan ini sebenarnya tidak hanya dilakukan pada saat kampanye pemilu, tetapi juga dalam momentum Pemilu di mana intensitas penyampaian hal-hal tersebut menjadi lebih banyak dilakukan kepada publik. Contohnya, kampanye terbuka di lapangan, rekruitmen kader baru, rekruitmen kader pemuda, rekruitmen kader perempuan, pengkaderan fungsional, pengkaderan desa, dan lain-lain. Selain itu, terdapat juga pelatihan khusus saksi dan pelatihan khusus anggota DPR partai Golkar.

Adapun media konvensional yang digunakan untuk kegiatan kampanye adalah radio, koran, televisi dalam bentuk liputan kegiatan besar (nasional) partai Golkar, seperti musyawarah nasional, kampanye akbar, dan juga iklan. Pemasangan spanduk, bendera, baliho, dan umbul-umbul juga masih dipakai, terutama dalam momentum pemilu. Hal ini sudah dilakukan Golkar sejak lama dan saat ini hanya mengikuti tradisi yang sudah lama dilakukan. 
Media baru atau media online yang juga digunakan oleh partai Golkar untuk kampanye adalah melalui media sosial, seperti Facebook, Instagram, YouTube, dan Twitter. Namun, kampanye menggunakan media sosial ini masih perlu disosialisasikan lebih banyak lagi di kalangan kader seperti yang diungkapkan oleh informan $\mathrm{H}$ berikut ini:

"Interaksi lebih banyak, tapi elektoralnya belum tentu. Pengguna media sosial tidak terbatasi ruang waktu, sedangkan target perolehan suara (electoral) ada masa waktunya dan batas wilayahnya"

Kegiatan public relations atau kehumasan tidak luput dari peranan media massa. Hal ini juga terbukti dengan Golkar selama 32 tahun menopang kekuasaan Orde Baru menjadikan citra Golkar sebagai partai pemerintah. Berdasarkan studi yang dilakukan Rachmiatie et. al. (2013), partai Golkar selangkah lebih maju dari partai-partai lain dalam penggunaan website dan call center. Bahkan, partai ini menerbitkan majalah bulanan di tingkat pusat dan buletin di tingkat provinsi. Hal tersebut yang menjadikan partai Golkar dalam komunikasi publik dan proses pencitraan tetap terdepan dibandingkan partai-partai lainnya. Golkar merupakan partai yang rutin melakukan publisitas di media massa baik di masa pemilu maupun jauh sebelum pemilu berlangsung.

Strategi komunikasi politik menurut Thompson (2001, dalam Zainal \& Sarwoprasodjo, 2018) terdiri dari beberapa unsur. Pertama, visi atau perspektif organisasi harus dijadikan acuan dalam mengatur lebih lanjut aktivitas komunikasi. Golkar memiliki visi yakni terwujudnya masyarakat Indonesia yang bersatu, berdaulat, maju, modern, damai, adil, makmur, beriman dan berakhlak mulia; memiliki kesadaran hukum dan lingkungan; menguasai ilmu pengetahuan dan teknologi; dan bermartabat dalam pergaulan dunia. Visi ini terlahir dari adanya paradigma baru yang mencoba mengubah pandangan bahwa Golkar bukan lah "partai penguasa" yang melegitimasi kekuasaan. Prinsip Golkar adalah doktrin karya kekaryaan yang kreatif dan dinamis mengikuti dinamika perkembangan zaman.

Kedua, organisasi menetapkan serangkaian rencana yang diturunkan dari visi dan misi. Visi Golkar didasarkan pada ideologi Pancasila dan doktrin karya kekaryaan. Untuk mewujudkannya, dibentuklah misi-misi yang terdiri dari: (1) menegaskan, mengamankan, dan mempertahankan Pancasila sebagai dasar negara dan ideologi bangsa; (2) mewujudkan cita-cita proklamasi melalui pelaksanaan pembangunan nasional di segala bidang untuk merealisasikan masyarakat yang demokratis dan berdaulat, sejahtera dan makmur, menegakkan supremasi hukum dan menghormati hak azasi manusia, serta terwujudnya ketertiban dan perdamaian dunia dan; (3) mewujudkan pemerintahan yang efektif dengan tata pemerintahan yang baik, bersih, berwibawa dan demokratis.

Ketiga, menetapkan taktik dengan pertimbangan internal dan keadaan di lapangan. Golkar mengalami penurunan jumlah perolehan suara dan kursi sejak Pemilu pertama di era Reformasi sampai saat ini. Hal ini disebabkan oleh partai Golkar yang menjalankan aktivitas komunikasi yang tidak sesuai kebutuhan pasar, seperti yang diungkapkan oleh informan AHS berikut ini: 
"Partai ini secara konsisten ditinggal pemilih dan tidak digandrungi pemilih baru karena produk yang ditawarkan adalah produk lama, tidak sesuai selera pasar. Sedangkan pasar berubah cepat seiring perubahan zaman."

Keempat, meletakkan posisi organisasi dan komponen komunikasi (komunikator, sumber, pesan, dan target sasaran), serta program dalam konteks lingkungan yang dihadapi. Para pemimpin di partai Golkar lebih banyak menirukan figur Soeharto yang sentral dan dapat menentukan segalanya, kecuali pada saat kepemimpinan Akbar Tanjung. Di bawah kepemimpinan Akbar Tanjung, Golkar menunjukkan keterbukaannya terhadap proses demokratisasi dalam wujud paradigma baru (Nurjaman, 2018). Hasil penelitian yang dilakukan oleh (Muchtar, 2013) menunjukkan komunikasi politik dalam hal penerapan paradigma baru yang dilakukan Golkar secara garis besar dapat dilihat pada Gambar 1.

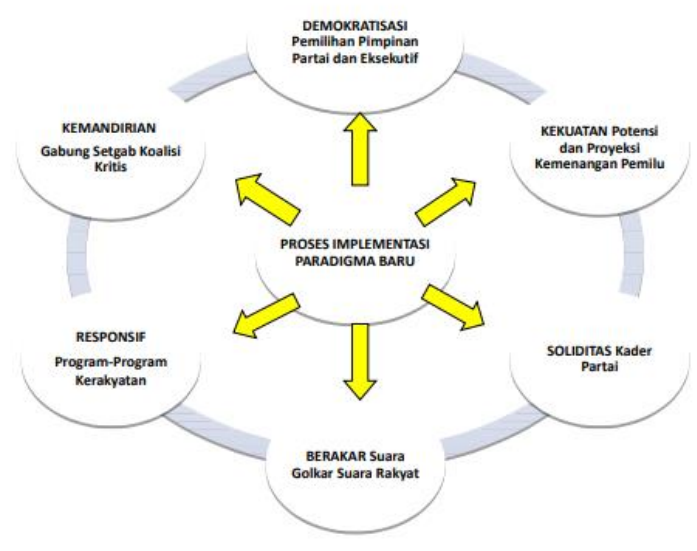

Gambar 1. Proses

paradigma baru Golkar (Muchtar, 2013)

implementasi

Kelima, menyusun pola aktivitas komunikasi dengan jelas agar dapat dijalankan oleh semua pelaku komunikasi. Kegiatan-kegiatan yang dilaksanakan partai Golkar mendorong tercapainya tujuan nasional yang berlandaskan pada ideologi Pancasila. Hal ini menjadi doktrin dalam kegiatan pendidikan pengkaderan bahwa semua memiliki hak dan kewajiban yang sama dan sudah diatur secara tegas dalam aturan partai, seperti yang disampaikan oleh informan $\mathrm{H}$ sebagai berikut:

"Di partai golkar ada istilah P-D-L-T (prestasi, dedikasi, loyalitas dan Tak Tercela), sebenarnya ini budaya organisasi Partai Golkar. Semua kader diukur dengan ini, aturannya begitu."

Pada umumnya, sebagian besar partai menggunakan strategi komunikasi politik melalui mesin politik partai. Golkar menggunakan dan menjadikan mesin partai dan organisasi masyarakat (ormas) sebagai andalan kegiatan sosialisasi politik (Rachmiatie et al., 2013). Hal ini dilakukan dalam kegiatan di acara-acara dan hari-hari besar keagamaan untuk berkomunikasi dengan konstituen.

\section{Marketing Politik Golkar}

Kriteria pemasaran politik berdasarkan (Nimmo, 2005) meliputi policy, person, party, dan presentation, Golkar sebagai partai yang sudah aktif berdiri sejak 1964 memiliki beberapa persamaan dan perubahan. Pertama, policy atau kebijakan partai 
Golkar. Golkar bertahan dengan kelembagaan yang telah dibangun dari masa Orde Baru sehingga jaringan organisasi sudah mencakup wilayah nasional dan nilai-nilai yang menjadi perekat soliditas organisasi (Tanjung, 2007). Kemudian, Golkar juga melakukan adaptasi pasca Reformasi dengan perombakan total agar dapat sejalan dengan nilai-nilai demokrasi, sehingga menjadi pijakan dasar dalam menentukan arah dan kebijakan organisasi (Rahman, 2017) Salah satunya adalah dengan melakukan musyawarah nasional luar biasa (munaslub).

Kedua, person yang merupakan pimpinan dan anggota partai Golkar tentu akan berubah setiap 5 tahun sekali. Pemimpin partai, baik ketua umum maupun pemimpin partai di daerah juga berperan sebagai komunikator. Komunikator sangat menentukan tercapainya tujuan, dalam hal ini kemenangan. Penelitian yang dilakukan oleh Narendra (2013) menyatakan bahwa strategi pemenangan melalui komunikasi politik yang dilakukan kandidat Golkar pada pemilu kepala daerah di wilayah Kabupaten Grobogan tahun 2011, di antaranya meliputi: (1) merawat ketokohan, yakni menjalankan pemerintahan secara normatif; (2) pemantapan kelembagaan dengan cara melaksanakan pertemuan rutin; (3) memahami khalayak dengan turun langsung bersama masyarakat; (4) menyusun pesan persuasif; (5) menetapkan metode yang sesuai untuk meneliti kondisi masyarakat; (6) memilah dan memilih media; (7) seni berkompromi melalui lobi dan negosiasi dan; (8) bersedia membuka diri terhadap semua lapisan masyarakat.

Ketiga, party yang meliputi visi dan misi, serta atribut partai Golkar. Baik visi, misi, serta atribusi di Golkar tidak ada yang berubah, seperti logo pohon beringin dan warna kuning. Hal ini dipertegas oleh informan AHS:

"Atribusi di partai Golkar tidak ada yang berubah sejak orde baru seperti logo dan warna, tagline berubah tapi sekedar jargon. Ini menunjukkan bahwa sebenarnya partai Golkar tidak berubah sejak pembentukannya pada era Orde Baru, dibentuk untuk dijadikan sebagai stempel kekuasaan Soeharto, hingga era reformasi tidak berubah. Wataknya masih sama, sampulnya cenderung masih sama. Ada beberapa berubah dipermukaan tapi masih sangat minim, isinya masih sama."

Keempat, yakni presentasi dari organisasi. Penerapan pemasaran politik menjadi penting semenjak era Reformasi karena adanya perubahan sistem sejak pemilu legislatif telah mendorong partai politik untuk melakukan perubahan (Simbolon, 2016).

Perubahan tersebut meliputi program-program partai yang ditawarkan dan cara mensosialisasikan (kampanye) partai. Salah satunya adalah dengan doktrin paradigma baru Golkar. (Muchtar, 2013) memberikan gambaran sosialisasi paradigma baru yang dilakukan Golkar seperti Gambar 2. 


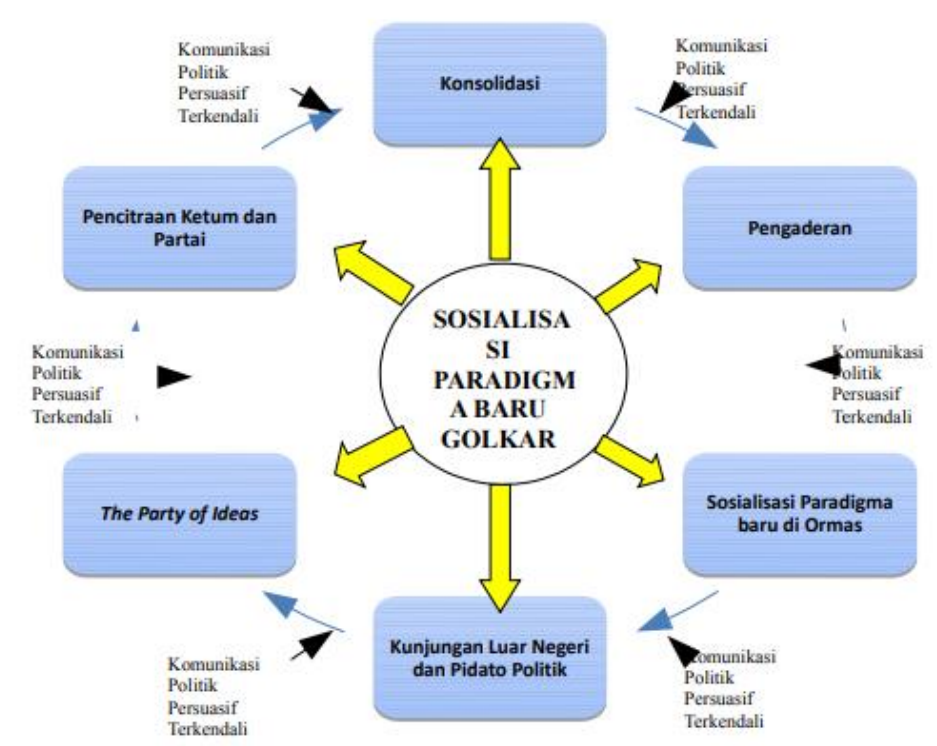

Gambar 2. Model sosialisasi paradigma baru Golkar (Muchtar, 2013)

Tujuan dari paradigma baru ini adalah untuk membangun citra politik yang positif yang dapat diterima khalayak. Bentuk sosialisasi ini dilakukan di sela-sela acara dan setiap ada kesempatan dengan memberikan pembinaan yang mengarah pada aspek-aspek paradigma baru tersebut, yang tetap berlandaskan pada ideologi Pancasila, seperti yang diutarakan oleh informan SBN:

"Dalam proses kampanye, tentu ideologi partai Golkar akan disampaikan secara tersirat, misalnya bahwa tujuan partai Golkar adalah tujuan nasional, ini menyampaikan ideologi partai sebagai partai nasionalis dan pro pemerintah. Demikian pula dalam acara acara seremoni misalnya menyanyikan "Hymne Partai Golkar", dalam lirik hymne tersebut penuh dengan doktrin dan impian ideal partai Golkar."

Merujuk pada pemasaran politik (Lees-Marshment, 2009), partai Golkar sedang mengarah kepada jenis market-oriented party. Menurut (Ufen, 2010), Golkar cenderung mengambil sikap yang lebih berorientasi pasar karena memiliki platform yang rumit, hampir tidak didasarkan pada lingkungan sosial dan/atau tradisi ideologis yang berbeda, sehingga lebih menyesuaikan dengan permintaan pasar, yakni para pemilih.

\section{KESIMPULAN}

Manajemen pemasaran komunikasi politik yang dilakukann Partai Golkar dilakukan melalui iklan politik dan hubungan masyarakat dengan menggunakan berbagai media. Adapun media yang digunakan untuk kegiatan partai diantaranya adalah radio, koran, televisi dalam bentuk liputan kegiatan besar (nasional) partai Golkar, seperti musyawarah nasional, kampanye akbar, dan juga iklan. Kegiatan komunikasi pemasaran politik yang dilakukan partai Golkar bertumpu pada mesin partai dan organisasi masyarakat yang mendukung partai agar sosialisasi dalam kegiatan-kegiatan besar dapat berjalan dengan lancar. Pemasaran politik, yakni policy, person, party, dan presentation partai Golkar, terutama pada unsur presentation perlu 
ditingkatkan agar citra politik semakin baik dan partai Golkar mendapatkan lebih banyak pendukung.

\section{DAFTAR PUSTAKA}

Bryman, A. (2012). Social Reserach Methods. New York, USA: Oxford University Press.

Dhani, R. (2004). Centang Perenang Manajemen Komunikasi Kepresidenan dari Soekarno sampai Megawati. Jakarta: LP3ES.

Firmanzah. (2012). Marketing Politik Antara Pemahaman dan Realitas. Jakarta: Yayasan Pustaka Obor Indonesia.

Lees-Marshment, J. (2009). The Product, Sales, and Market Oriented Party: How Labour Learnt to Market the Product, not Just Presentation. European Journal ov Marketing, 35(9/10), -.

Maryani, D. (2015). The Analysis Of Political Marketing Mix In Influencing Image And Reputation of Political Party And Their Impact Toward The Competitiveness Of Political Party The Survey Of Voters In West Java Province. International Journal of Scientific \& Technology Research, 4(8), 101-111.

McNair, B. (2011). An Introduction to Political Communication. London and New York: Routledge.

Muchtar, K. (2016). Komunikasi Politik dan Pembentukan Citra Partai. Jurnal Ilmu Komunikasi, 14(2), 136-147.

Muchtar, K. (2013). Komunikasi Politik Partai Golkar Dalam Proses Sosialisasi Dan Implementasi Paradigma Baru Masa Kepemipinan Aburizal Bakrie 2009 - 2013. Jurnal Penelitian Komunikasi, 16(2), 101-118. https://doi.org/10.20422/jpk.v16i2.34

Narendra, R. A. (2013). Strategi Komunikasi Politik Pasangan Bambang-Icek Dalam Pemilihan Umum Kepala Daerah Kabupaten Grobogan Tahun 2011. 3(1), 33-46. https://doi.org/10.14710/politika.3.1.2012.33-46

Neuman, W. L. (2014). Social Research Methods: Qualitative and Quantitative Approaches. USA: Pearson.

Nimmo, D. (2005). Komunikasi Politik dan Efek. Bandung: Remaja Rosdakarya.

Nurjaman, A. (2018). Masa Depan Faksionalisme Politik Golkar Pasca Orde Baru.4(2), 34-48.

Pujono, Muktiyo, W., \& Hastjarjo, S. (2015). Strategi Komunikasi Politik Calon Legislatif Partai Golkar dalam Memenangkan Pemilihan Umum 2014 di Kabupaten Sragen. Jurnal Ilmu Komunikasi, 13(3), Pendahuluan Dalam sistem politik yang demokratis,.

Rachmiatie, A., Hasbiansyah, O., Khotimah, E., \& Ahmadi, D. (2013). Strategi Komunikasi Politik dan Budaya Transparansi Partai Politik. MIMBAR, Jurnal Sosial

Dan

Pembangunan,

29(2),

123. 
https://doi.org/10.29313/mimbar.v29i2.384

Rahman, M. R. T. (2017). Dilema Pelembagaan Partai Golongan Karya (Golkar) Di Tingkat Lokal: Fenomena Politik Klan. CosmoGov, 2(1), 160. https://doi.org/10.24198/cosmogov.v2i1.11855

Saputra, M. I., Haryono, B. S., \& Rozikin, M. (2013). Marketing Politik Pasangan Kepala Daerah Dalam PEMILUKADA (Studi Kasus Tim Sukses Pemenangan Pasangan Abah Anton dan Sutiaji dalam Pemilukada Kota Malang 2013). Administrasi Publik, 2(2), 250-256.

Simbolon, F. (2016). Political Marketing Mix in Indonesia Parties. Binus Business Review, 7(1), 103. https://doi.org/10.21512/bbr.v7i1.1490

Suryadinata, L. E. O. (2007). of the Hegemonic in Indonesia : Party System Golkar after the Fall of Soeharto The Decline. 29(2), 333-358. https://doi.org/10.1355/cs29-2f

Sudibyo, A. (2004). Ekonomi Politik Media Penyiaran. Yogyakarta: ISAI-LKiS.

Tanjung, A. (2007). The Golkar Way: Survival Partai Golkar di Tengah Turbulensi Politik Era Transisi. Gramedia Pustaka Utama.

Tomsa, D. (2007). Party Politics and Media in Indonesia: Creating a New Dual Identity for Golkar. Contemporary Southeast Asia: A Journal of International and Strategic Affairs, 29(1).

Ufen, A. (2010). Electoral Campaigning in Indonesia : The.

Zainal, A. G., \& Sarwoprasodjo, S. (2018). Strategi Komunikasi Politik Pemerintahan Daerah dalam Meningkatkan Partisipasi Masyarakat Pedesaan (Studi Program "Bupati Ronda" di Kabupaten Lampung Tengah). Journal Of Communication Studies, 3(1), 54-66. 